\title{
Technology as gamification means in mathematics learning
}

\author{
Alién García-Hernández ${ }^{1}$, Teresa González-Ramírez ${ }^{2}$
}

${ }^{1}$ Faculty of Computer Science and Technology, Universidad de las Ciencias Informáticas, Cuba, ${ }^{2}$ Faculty of Education Sciences, Universidad de Sevilla, Spain.

\begin{abstract}
Discrete Mathematics is a highly complex university subject. Its classes are taught in a traditional way, so in many cases they do not motivate students. This study develops dynamics of gamification to promote a better learning of Discrete Mathematics, in the same way, it seeks to influence the engagement of students in this university subject. 178 students participate in this quasiexperiment (90 in the control group and 88 in the experimental group). The pretest and posttest data of the academic performance and engagement of the experimental group and the control group display that, in terms of progress, the experimental group showed significant progress compared with the control group. The study is concluded by raising the possibility of applying other games and game dynamics that promote a greater variety of gamified activities. In this sense, it is proposed to investigate the effects of the use of games in mobile application format on both engagement and academic performance in Discrete Mathematics.
\end{abstract}

Keywords: Mathematics; gamification; academic performance; engagement; educational technology. 


\section{Introduction}

Within engineering, mathematics plays a much more relevant role than in other subjects, the content and the need for its learning become more complex. A part of mathematics known as Discrete Mathematics (DM) takes on special interest within computational careers, in charge of the study of discrete processes and in which uncommon contents are grouped in university "classical mathematics" such as Graph Theory, Logic , Combinatorial Theory, Recurrence Relations, among others (Pokorny, 2013). The objectives of the Discrete Mathematics are directed, among other aspects, to the modeling and simulation of structures and processes involved in the computational solution of problems (González-Ramírez \& GarcíaHernández, 2020).

Traditional teaching methods are used today in the DM teaching-learning process. As a result, some students find this subject boring. If there is no interest, students do not focus on the classes and make little effort to learn. This is a challenging problem for teachers (Liang, Zhang, Long, Deng, \& Liu, 2020). Among the different activities that can be used to implement an active learning methodology, previous research shows that the use of games with educational purposes facilitates students' assimilation of the ideas and concepts introduced in class as well as improves students' academic performance and engegament (Gil-Doménech \& Berbegal-Mirabent, 2019)

Gamified learning is defined as a strategy to employ game elements (e.g., points, levels, and challenges) in learning contexts to promote students' learning. For example, in gamified learning activities, students earn experience points after successfully accomplishing certain tasks by themselves (Sun-Lin \& Chiou, 2019). The gamification design would facilitate students' learning because game elements encourage students to engage in learning tasks, perceive what they experience, and decide what to do in learning process (Chiu \& Hsieh, 2017).

\section{Material and Methods}

The aim of this study is to investigate whether the use of game based assessment activities in the classroom is more effective than traditional evaluation for improving the academic performance and engagement of discrete mathematics learning.

A quasi-experimental design was employed in this study to asses the efects of the gamification in the engagement and academic performance of Discrete Mathematics. 178 freshman students from the same university participated in this experiment, with 88 participants assigned to the experimental group and 90 to the control group. The experimental group learned Discrete Mathematics through gamified activities. Traditional classes methodology was employed for the control group in this teaching experiment. In this passive 
teaching method, the teacher typically explains the unit content according to the university syllabus, with the students listening in their seats and solving exercises in their notebooks.

In terms of dependent variables, academic performance refers to the pre- and post-test results of an institutional test on academic achievement in Discrete Mathematics (with an evaluation scale from 2 to 5 , where 2 is failure and 5 is excellent). An instrument that we designed and validated in a previous investigation (González-Ramírez \& García-Hernández, 2020) was used to assess engagement towards learning Discrete Mathematics (the other independent variable). This scale includes seven dimensions: level of autonomy, satisfaction with study materials, student well-being, student self-efficacy, activity in the classroom, feedback and learning environment. A Likert five-point scale was used, and a higher score indicated a higher satisfaction toward the learning system. The teaching duration for both groups was eigth lessons ( $25 \%$ of whole course).

\subsection{Data analysis}

First, the nature of the dependent variables was determined to check if their distribution is normal, applying the Normality Tests with the Kolmogorov-Smirnov statistic. In this research, the variables followed a normal distribution, so Parametric Contrasts were performed, in this case Student's T-test for two independent samples in order to determine the equality of means, to which the Levene Test was previously performed, to analyze the equality of variance.

\subsection{Intervention}

Students face a virtual game where they answer various questions associated with Discrete Mathematics to obtain points. Depending on the complexity of the question, points are awarded from 1 to 5 (where 5 represents the maximum complexity) (Figure 1). The highest scoring students get academic rewards as validation of assessments.

\section{Aprende jugando y compitiendo (Teoría de Grafos)}

Pregunta*

Determine y justifique la veracidad de la siguiente proposición expresada sobre el grafo $\Psi$ :

$$
\operatorname{deg}(\alpha)+\operatorname{deg}(\beta) \geq n ;|V(\Omega)|=n, \forall n \geq 3 ; \forall(\alpha, \beta) \text { no adyacentes y } \alpha \neq \beta
$$

Máximo de puntos a obtener: 5

Figure 1. Interface where the student learns by competing in solving problems. 
Similarly, students get points if they propose an exercise for the competition and it is accepted by the professor. They can also solve crosswords as a game (Figure 2). Completing a crossword represents a level of mastery over the topic at hand.

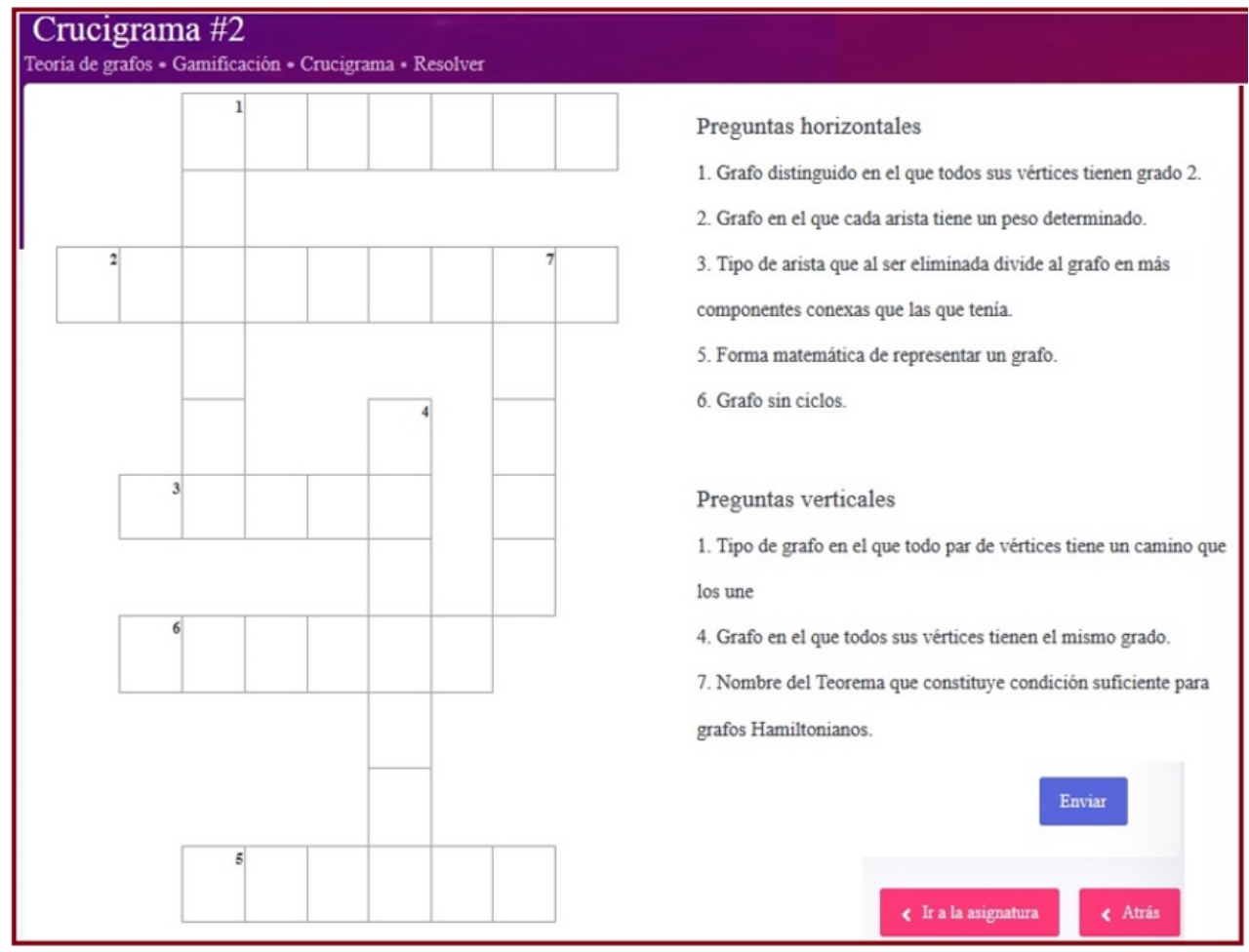

Figure 2. Interface where the student learns by solving crosswords.

\section{Results}

The pretest and posttest data of the academic performance of the experimental group and the control group are shown in Table 1. Results of the "t-test" analysis showed significant difference $(p<.001)$ between the groups. In terms of progress, the experimental group showed significant progress in academic performance compared with the control group. The control group, on the contrary, showed almost no differences between the pretest and posttest. This indicated that the application of gamification was effective in promoting significant progress in academic performance of Discrete Mathematics. 
Table 1.The pretest and posttest data of the academic performance.

\begin{tabular}{|c|c|c|c|c|c|c|c|c|}
\hline \multirow{2}{*}{ Variable } & \multicolumn{3}{|c|}{ Control group $\mathbf{n = 9 0}$} & \multicolumn{3}{|c|}{ Experimental group $n=88$} & \multirow{2}{*}{$\begin{array}{c}\text { Difference } \\
\text { Both } \\
\text { groups } \\
\end{array}$} & \multirow{2}{*}{$\begin{array}{c}\text { t-test } \\
p\end{array}$} \\
\hline & $\begin{array}{l}\text { pre- } \\
\text { test }\end{array}$ & post-test & progress & $\begin{array}{l}\text { pre- } \\
\text { test }\end{array}$ & post-test & progress & & \\
\hline $\begin{array}{l}\text { Academic } \\
\text { performance }\end{array}$ & 2.78 & 2.89 & 0.11 & 2.81 & 3.97 & 1.16 & 1.05 & 0.000 \\
\hline
\end{tabular}

Similarly, as shown in table 2, results of the "t-test" analysis showed significant difference $(p<.001)$ between the groups in each factor of the scale to assess engagement towards learning Discrete Mathematics. The experimental group increased their levels of engagement towards learning of Discrete Mathematics.

Table 2. The pretest and posttest data of the scale to assess engagement towards learning Discrete Mathematics.

\begin{tabular}{|c|c|c|c|c|c|c|c|c|}
\hline \multirow[b]{2}{*}{ Variable } & \multicolumn{3}{|c|}{ Control group $n=90$} & \multicolumn{3}{|c|}{ Experimental group $n=88$} & \multirow{2}{*}{$\begin{array}{c}\text { Difference } \\
\text { Both } \\
\text { groups }\end{array}$} & \multirow{2}{*}{$\begin{array}{c}\text { t-test } \\
p\end{array}$} \\
\hline & $\begin{array}{l}\text { pre- } \\
\text { test }\end{array}$ & post-test & Progress & $\begin{array}{l}\text { pre- } \\
\text { test }\end{array}$ & post-test & Progress & & \\
\hline $\begin{array}{l}\text { Level of } \\
\text { autonomy }\end{array}$ & 3.54 & 3.62 & 0.08 & 3.21 & 4.28 & 1.07 & 0.99 & 0.000 \\
\hline $\begin{array}{l}\text { Satisfaction } \\
\text { with study } \\
\text { materials }\end{array}$ & 1.93 & 1.85 & -0.08 & 1.78 & 4.57 & 2.79 & 2.87 & 0.000 \\
\hline $\begin{array}{l}\text { Student } \\
\text { well-being }\end{array}$ & 2.18 & 2.23 & 0.05 & 2.08 & 3.12 & 1.04 & 0.99 & 0.000 \\
\hline $\begin{array}{l}\text { Student self- } \\
\text { efficacy }\end{array}$ & 1.78 & 2.01 & 0.23 & 2.12 & 4.19 & 2.07 & 1.84 & 0.000 \\
\hline $\begin{array}{l}\text { Activity in } \\
\text { the } \\
\text { classroom }\end{array}$ & 2.21 & 2.87 & 0.06 & 2.52 & 3.99 & 1.47 & 1.41 & 0.000 \\
\hline Feedback & 2.72 & 2.58 & -0.14 & 2.64 & 4.15 & 1.51 & 1.65 & 0.000 \\
\hline $\begin{array}{l}\text { Learning } \\
\text { environment }\end{array}$ & 3.02 & 3.17 & 0.15 & 2.99 & 4.15 & 1.16 & 1.01 & 0.000 \\
\hline
\end{tabular}

\section{Discussion and conclusion}

We can highlight, after empirical processing, that there are significant differences between the average score obtained in the pre and post-test evaluation with the academic performance in Discrete Mathematics in the group that performs the experiment. This result confirms that 
the use of gamification is a determining factor in academic performance (Gil-Doménech \& Berbegal-Mirabent, 2019; Liang et al., 2020; Sun-Lin \& Chiou, 2019).

Similarly, there are significant differences between the average score obtained in the pre and post-test evaluation in the Questionnaire to measure the levels of student engagement with their learning of Discrete Mathematics. The students of the experimental group made a greater effort to pass the subject, coinciding with Reyes-de Cózar (Reyes, 2016). The students considered that the use of the games led to better communication with their classmates and teachers; it also motivated them to win the course.

They also perceived greater feedback from their teachers both in their constant doubts and in the review of evaluations. This coincides with the theoretical references on the subject and makes us empirically evidence the importance of feedback for student engagement (Kyaruzi, Strijbos, Ufer, \& Brown, 2019), enhancing the use of the possibilities offered by technologies to contribute to the learning of students (Amaya, García-Hernández, \& Cañas, 2017). It is worth noting that the activities in the classroom were characterized by a better management of the teacher, favoring an accurate technological mediation that raised the levels of engagement towards the learning of Discrete Mathematics (García-Hernandéz \& GonzalezRamirez, 2017).

This study allows us to validate that gamification is also effective in Higher Education to promote better learning in highly difficult subjects. It is worth noting that it would be interesting to apply other games and game dynamics that promote a greater variety of gamified activities. In this sense, it is proposed to investigate the effects of the use of games in mobile application format on both engagement and academic performance in Discrete Mathematics.

\section{References}

Amaya, D., García-Hernández, A., \& Cañas, A. (2017). Perception on the contribution of Interactive and Experimental Learning Objects to the management of learning in Discrete Mathematics [Percepción sobre la contribución de los Objetos de Aprendizaje Interactivos y Experimentales a la gestión del aprendizaj. 10th International Conference of Education, Research and Innovation, 8926-8933. Seville, Spain. https://doi.org/10.21125/iceri.2017.2487

Chiu, F. Y., \& Hsieh, M. L. (2017). Role-playing game based assessment to fractional concept in second grade mathematics. Eurasia Journal of Mathematics, Science and Technology Education, 13(4), 1075-1083. https://doi.org/10.12973/eurasia.2017.00659a

García-Hernandéz, A., \& Gonzalez-Ramirez, T. (2017). Design and assessment of the impact of an e-textbook in the engagement towards the learning of Discrete Mathematcs. $A C M$ International Conference Proceeding Series, Part F1322. https://doi.org/10.1145/3144826.3145443

Gil-Doménech, D., \& Berbegal-Mirabent, J. (2019). Stimulating students' engagement in mathematics courses in non-STEM academic programmes: A game-based learning. 
Innovations in Education and Teaching International, 56(1), 57-65. https://doi.org/10.1080/14703297.2017.1330159

González-Ramírez, T., \& García-Hernández, A. (2020). Estudio de los factores de estudiantes y aulas que intervienen en el "engagement" y rendimiento académico en Matemáticas Discretas. Revista Complutense de Educación, 31(2), 195-206. https://doi.org/10.5209/rced.62011

Kyaruzi, F., Strijbos, J., Ufer, S., \& Brown, G. (2019). Students' formative assessment perceptions, feedback use and mathematics performance in secondary schools in Tanzania [Percepciones de la evaluación formativa de los estudiantes, la retroalimentación y el rendimiento matemático en escuelas secundarias en. Assessment in Education: Principles, Policy and Practice, 26(3), 278-302. https://doi.org/10.1080/0969594X.2019.1593103

Liang, Y., Zhang, L., Long, Y., Deng, Q., \& Liu, Y. (2020). Promoting Effects of RtI-Based Mathematical Play Training on Number Sense Growth among Low-SES Preschool Children. Early Education and Development, 31(3), 335-353. https://doi.org/10.1080/10409289.2019.1664261

Pokorny, M. (2013). Blended Learning as an Efficient Method for Discrete Mathematics Teaching [Aprendizaje combinado como un método eficiente para la enseñanza de la Matemática Discreta]. 2013 International Conference on Education and Educational Research EER 2013, 249-252.

Reyes, S. (2016). Fortalecer la implicación y el compromiso de los estudiantes con la universidad. Una visión multidimensional del engagement. (Universidad de Sevilla). Universidad de Sevilla. Retrieved from bit.ly/2VhtEED

Sun-Lin, H. Z., \& Chiou, G. F. (2019). Effects of Gamified Comparison on Sixth Graders ' Algebra Word Problem Solving and Learning Attitude. Journal of Educational Technology \& Society, 22(1), 120-130. 